\title{
EFFECT OF YOGA AND PILATES ON ACADEMIC STRESS AMONG COLLEGE STUDENTS
}

\section{Sandhiya ${ }^{* 1}$ P. Senthil Selvam ${ }^{2}$, M.S. Sundaram ${ }^{3}$, Fouzia Banu. B 4 .}

${ }^{*}$ Assistant Professor, Vels University, School of Physiotherapy, Rajiv Gandhi salai, near navalur, Thalambur, OFF (OMR), Chennai, Tamil Nadu, India.

${ }^{2}$ Professor, Vels University, School of Physiotherapy, Rajiv Gandhi salai, near navalur, Thalambur, OFF (OMR), Chennai, Tamil Nadu, India.

${ }^{3}$ Professor, Vels University, School of Physiotherapy, Rajiv Gandhi salai, near navalur, Thalambur, OFF (OMR), Chennai, Tamil Nadu, India.

${ }^{4}$ Intern, Vels University, School of Physiotherapy, Rajiv Gandhi salai, near navalur, Thalambur, OFF (OMR), Chennai, Tamil Nadu, India.

\section{ABSTRACT}

Introduction: According to WHO , Academic stress means education related stresses it can be in every situation otherwise feel stress. It is the main source of stress faced by young people. Many researchers agrees that the most ordinary appearance of anxiety cause academic stress is achievement anxiety. Some researchers have argued that in East Asian countries especially, this academic stress-suicidal ideation link among adolescents could possibly be even stronger given the familial and cultural demands for academic excellence. Specifically, in an Asian context, academic stress arising from adolescents self -expectations and expectations of others (e.g., parents and teachers ) are particularly salient. Thus

Aim of the study: The main aim of the study is to find out the efficacy of the Yoga \& Pilates on academic stress among college students.

Participants: 70 samples those who full filled inclusion and exclusion criteria were taken for the study. Samples divided into equal two groups.

Intervention: One group received pilates and other group received yoga respectively.

Results: The $t$ values of the Group A \& B is 6.5245 and 5.6151 respectively and $p<0.0001$.

Conclusion: This study concluded that there is significant reduction in academic stress among both pilates and yoga groups.

KEY WORDS: Academic stress, Pilates, Yoga, Academic stress scale, College students.

Address for correspondence: M. Sandhiya, MPT (ortho), (Ph.D), Vels University, School of Physiotherapy, Rajiv Gandhi salai, near navalur, Thalambur, OFF (OMR), Chennai- 600130, , Tamil Nadu, India. Phone no.99040583928 E-Mail: sandhiya.sp@velsuniv.ac.in

Access this Article online

Quick Response code

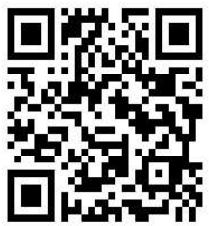

DOI: $10.16965 /$ ijpr.2020.150

Journal Information

\section{International Journal of Physiotherapy and Research}

ISSN (E) 2321-1822 | ISSN (P) 2321-8975

https://www.ijmhr.org/ijpr.html

DOI-Prefix: https://dx.doi.org/10.16965/ijpr

\section{Article Information}

Received: 03 Jul 2020

Peer Review: 03 Jul 2020

Revised: None
Accepted: 12 Aug 2020

Published (O): 11 Sep 2020

Published (P): 11 Oct 2020

\section{INTRODUCTION}

In current generation, the academic stress has become a buzz among students. As a result of globalization and modern age has became more highly competitive world, so the students must face many problems that may lead them to stress in their academic year.

According to WHO, Academic stress means 
education related stresses it can be in every situation otherwise feel stress. It is the main source of stress faced by young people. Some students often feel high academic burden fewer contentment related their scholastic achievement. Many researchers agree that the most ordinary appearance of anxiety causes academic stress is achievement anxiety [1].

The achievement anxiety is a terror of failure in an academic situation that arises when the parents, teachers otherwise the student's expectations go beyond the practical performance.

Adrenaline increase the heart rate, elevates the blood pressure and boosts energy supplies. Cortisol, the primary stress hormone, increases sugar (glucose) in the bloodstream, enhances the brain's use of glucose and increases the availability of substances that repair tissues

Cortisol is a steroid hormone produced by the adrenal gland. The hormone is released in response to stress and low levels of blood sugar $\&$ its primary function is to increase blood sugar levels, suppress the immune system and aid in metabolism. Cortisol is a stress hormone that has many functions.

Academic stress is a growing problem not only in India but all over the globe where students are more stressed than ever. Suicide is one of the three leading causes of death for adolescents and young adults worldwide. ${ }^{1} \mathrm{It}$ is therefore not surprising that adolescents who attempted suicide often had problem in school. Toero et al argued that there is a strong link between the pressure to excel in school and suicidal behaviours among children and adolescents [2].

Some researchers have argued that in East Asian countries especially, this academic stresssuicidal ideation link among adolescents could possibly be even stronger given the familial and cultural demands for academic excellence. Specifically, in an Asian context, academic stress arising from adolescents self-expectations and expectations of others (e.g., parents and teachers) are particularly salient [3].

Although the reasons are myriad but failure in examination, unemployment, and depression are the major factors that tends to be stimulating .The best time of the life that students are supposed to enjoy and cherish and that is the time they are pushed to extreme levels which can be overwhelming for many [4].

YOGA: Yoga is a physical, mental and spiritual practice that originated in ancient India. It became popular in the west in the $20^{\text {th }}$ century. The yoga comes from the Sanskrit word "YUJ" meaning yoke or union. Thus, yoga is the practice that aims to join the MIND, BODY \& SPIRIT. It incorporates breathing exercise, meditation \& poses designed to encourage relaxation \& reduce stress. With increasing scientific research in yoga, its therapeutic aspects are also being explored [4].

Yoga is known for its ability to ease stress, anxiety and promote relaxation, improves autonomic function by triggering neurohormonal mechanisms by the suppression of sympathetic activity, and even, now-a-days, several reports suggested yoga is beneficial for physical health of patients ${ }^{4}$ In fact, multiple studies have shown that it can decrease the secretion of cortisol, the primary stress hormone.

PILATES: Functional Pilates [Filates] is a series of exercise followed by soft tissue manipulation that enhances the optimal function of neuromyofacial system of human body.

Pilates is an excellent way to trim down your body and strengthen core muscles without bulking up. This style of exercise will teach you how to control your body movements and increase your flexibility and grace. Joseph Pilates originally considered this to be a body/mind/ spirit approach to movement founded on the integrative effect of principles, Centring, Breathing, Movement flow / Rhythm.

Pilates exercise does a lot of things to our body. Unlike other exercises which can cause stress and injuries. It can help to develop a healthy body by promoting blood to run deeply into your whole system, instead of causing stress [5]. Reduced levels of stress as wellas improved respiratory and circulatory system are all direct benefits of pilates training [6]. Pilates is reducing the stress by the action of decreasing the cortisol through the breathing pattern.

Aim of the study: To find out the efficacy of the Yoga \& Pilates on academic stress among college students. 
M. Sandhiya P. Senthil Selvam, et all., EFFECT OF YOGA AND PILATES ON ACADEMIC STRESS AMONG COLLEGE STUDENTS.

\section{Objectives of the Study:}

- To find out the academic stress among the college student.

- To find out the effect of yoga on academic stress.

- To find out the effect of pilates on academic stress.

To compare the contrast effect of the yoga and Pilates on academic stress

\section{MATERIALS AND METHODS}

Procedure: The convenient sample of 70 bachelor of physiotherapy students were recruited for the study. They were recruited according to the inclusion and exclusion criteria. Inclusion criteria are 17-22 both genders, moderate and high intensity academic stress score. Exclusion criteria Mentally disturbed persons/mentally ill persons, Hypertensive, Vertigo, Seizure/fits, Asthamatics, Any sort of musculoskeletal pain.

The procedure was adequately explained to the participants before obtaining their informed consents. The concern participants agreed that they would not engage in any other exercises for the 8 week period. Then the participants were randomly divided into 2 groups.Group A 35 participants and YOGA. Group B 35 participants and received PILATES.

For Group - A provided an opportunity to trained with ASANAS \& PRANAYAMAS for 45minutes including warm up and cool down sessions.

For Group - B Provided an opportunity to trained with pilates in frame approach of shoulder, hip, pelvic, spine for 45 minutes including warm up and cool down sessions.

\begin{tabular}{|c|c|c|}
\hline S.No. & YOGA & TIME \\
\hline \multirow{5}{*}{1} & \multicolumn{2}{|l|}{ ASANAS } \\
\hline & Pawanmuktasana & 3 to 5 rounds $5 \mathrm{~min}$ \\
\hline & Suptavajrasana & 3 to 5 rounds $5 \mathrm{~min}$ \\
\hline & Hasttutasana & 3 to 5 rounds $5 \mathrm{~min}$ \\
\hline & Bhujangasana & 3 to 5 rounds $5 \mathrm{~min}$ \\
\hline \multirow[t]{2}{*}{2} & Savasana & $10 \mathrm{~min}$ \\
\hline & \multicolumn{2}{|l|}{ PRANAYAMA } \\
\hline \multirow[t]{2}{*}{3} & Nadishodhan pranayama & $5 \mathrm{~min}$ \\
\hline & Bramari pranayama & $5 \mathrm{~min}$ \\
\hline
\end{tabular}

\begin{tabular}{clc} 
S.NO. & \multicolumn{1}{c}{ PILATES } & \multicolumn{1}{c}{ TIME } \\
\hline $\mathbf{1}$ & WARM UP SESSION & \\
\hline & Standing roll down & $5 \mathrm{~min}$ \\
\hline & Stamina stretch & $5 \mathrm{~min}$ \\
\hline $\mathbf{2}$ & FRAME APPROACH EXERCISES & \\
\hline & Frame Technique in Shoulder & $\mathbf{3}$ to 5 rounds $5 \mathrm{~min}$ \\
\hline & Frame technique in Hip & 3 to 5 rounds $5 \mathrm{~min}$ \\
\hline & Frame Technique in Pelvic & 3 to 5 rounds $5 \mathrm{~min}$ \\
\hline \multirow{3}{*}{ Frame Technique in spine } & 3 to 5 rounds $5 \mathrm{~min}$ \\
\hline $\mathbf{3}$ & COOL DOWN SESSION \\
\hline
\end{tabular}

\section{RESULTS}

The $t$ values of the Group A \& B is 6.5245 and 5.6151 respectively and $p<0.0001$. As for the analysis both the group shown the significant effect on academic stress.

Table 1: Showing the pre and post results of academic stress.

\begin{tabular}{|c|c|c|c|c|c|c|}
\hline & & Mean & Mean Diff & $\begin{array}{l}\text { Standard } \\
\text { deviation }\end{array}$ & T value & $P$ value \\
\hline \multirow{2}{*}{ YOGA } & PRE TEST & 46.77 & \multirow{2}{*}{25.74} & 19.86 & \multirow{2}{*}{6.5245} & \multirow{2}{*}{$<0.0001$} \\
\hline & POST TEST & 21.03 & & 12.27 & & \\
\hline \multirow{2}{*}{ PILATES } & PRE TEST & 47.49 & \multirow{2}{*}{25.32} & 21.55 & \multirow{2}{*}{-5.6151} & \multirow{2}{*}{$<0.0001$} \\
\hline & POST TEST & 22.17 & & 15.72 & & \\
\hline
\end{tabular}

\section{DISCUSSION}

There are numerous researches conducted across the world which showed that because of the elevated competition, constant strain and burden to perform efficiently in academics students of all the levels suffer poor psychological health. There is a need to provide facilities to the students in order to help them to deal with mental health issues.

Various physical exercises, meditation technique, art, dance and music therapies also proved to be beneficial to deal with stress, depression, anxiety and other psychological problems. Yoga therapy is one of the major exercise which emerged to be advantages and being used since long time.

The previous results found in the study conducted by Memmedova et al (2017 Nov) concluded that besides the physical and health benefits pilates exercises, have a positive result on neuro psychological variable such as anxiety, motivation and attention of students academic achievement [educational benefits] Another study done by k.kanimozhi et al (2018) concluded that the participant receive shambavimahamudra yoga had reduce the 
stress [relief] improve the flexibility. So shambavimahamudra yoga enhanced through CBT which has been chosen as a scientific tool for stress analysis and stress reduction has reduced the students distraction from study and day to day life activities and improve their academic and overall performance.

The current study, mean difference of the variables between pre test and post phase are shown in the form of table.

The t-ratio of yoga on academic stress is found to be $6.5245^{* *}$ which is showing significant difference among pre test score and post score (p 0.0001). Mean score (M) obtained on pre - test is 46.77 and on post - test is 21.03 . It shows that after post test phase scores on academic stress remarkably decreased which indicates that after yoga training students showed less symptoms of academic stress.

The t-ratio of pilateson academic stress is found to be $5.6151^{* *}$ which is showing significant difference among pre test score and post score (p 0.0001). Mean score (M) obtained on pre - test is 47.49 and on post - test is 22.17 . It shows that after post test phase scores on academic stress remarkably decreased which indicates that after pilates practicing students showed less symptoms of academic stress.

Findings of the present study clearly showed that yoga training and pilates function as moderator which enhance lower down the academic stress.

Pilates can be incredibly powerful in providing a place for the body to relax, rejuvenate and release tension. The pilates principle, breath, oxygenates the blood which triggers the brain to calm down. The breath creates a physiological response in the body that naturally decrease our stress and anxiety.

The practice of yoga synchronizes human physiology through controlled postures, breathing, meditation, a set of regular physical exercises and relaxations. Certain type yoga practice improve autonomic nervous system by modulating parasympathetic and sympathetic activity, significant changes in brain rhythms, sensory motor rhythm and regulation of breathing rate and improvement in the cardiac activity and enhance the sense of well being. [4]. Yoga and pilates both show the significant improvement in reducing academic stress but yoga is a traditional way for stress management and it was found queit difficult to follow it regularly by students. In case of pilates, a student were participating actively and were enjoying themselves during exercise period. And as compare to yoga pilates are easy to practice and even easy to learn and follow it.

Limitation of the study: The following were the limitation of our study: study includes only college going students, small sample size and using only one outcome measure

Future scope: The present study comprises of college students a future study can be done on school students. And further studies in this academic stress may overcome the limitations of this study by using a large sample size, comparing the effectiveness of academic stress and memory power of the student .

\section{CONCLUSION}

This study concluded that there is significant reduction in academic stress in both pilates and yoga groups.

\section{Conflicts of interest: None}

\section{REFERENCES}

[1]. United Nations. Prevention of suicide: guidelines for the formulation and implementation of national strategies (Document No. ST/ESA/245). United Nations Dept for policy coordination and sustainable Development, New York, NY 1996.

[2]. Toero K, Nagy A, Sawaguchi T, Sawaguchi A, Sotonyi P. Characteristics of suicide among children and adolescents in Budapest, Pediatr Int. 2001;43:368-371. https://doi.org/10.1046/j.1442-200X.2001.01414.x PMid:11472581

[3]. Rebecca P. Ang . Vivien S. Huan. Relationship between Academic stress and suicidal Ideation: Testing for Depression as a Mediator Using Multiple Regression ; Child Psychiatric Hum Dev 2006;37:133-143.

https://doi.org/10.1007/s10578-006-0023-8 PMid:16858641

[4]. K. Kanimozhi, B. Raja Mohamed Rabi. Yoga enhanced CBT for stress reduction; international journal of chem Tech Research 2018;11.

[5]. Austin D. Pilates for everybody, strengthen, lengthen and tone with this complete 3-week body makeover. Rodale, USA. 2002

[6]. Essam Abdel - Hamid Hassan and Manal Ahmed Amin. Pilates exercise influence on the Serotonin Hormone, Some Physical Variables and the Depression Degree in Battered Woman ; world journal of Sport Sciences 2011;5(2):89-100. 
[7]. Shilpa Singh Rohilla. Effect of Yoga on mental health, academic stress and life satiafaction ; IJSART 2018;4.

[8]. Konul Memmedova et al. Analysis of the effect of pilates exercises on motivation, anxiety, attention and academic achievement among university students ; International journal of scientific study2017;5.

[9]. Vikash K Twari et al. Is yoga an effective modality of stress reduction within medical population qualitative study within MBBS students of BRD medical college ; International journal of Research in medical science 2007;6(2). https://doi.org/10.18203/ 2320-6012.ijrms20180302

[10]. Caldwell et al. Effect of pilates and taijiquan training on self efficacy, sleep quality, mood, and physical performance of college students; journal of body works and movement therapy 2009;13(2):55-163. https://doi.org/10.1016/j.jbmt.2007.12.001 PMid:19329051

[11]. Aria $n$ R Aladro-Gonzalvo. et al. The effect of pilates exercises on body composition: A systematic review ; Journal of Bodywork \& Movement Therapies 2012;16:109e114. https://doi.org/10.1016/j.jbmt.2011.06.001 PMid:22196436
[12]. Chapell. Mark S et al. Test Anxiety and Academic performance in Undergraduate and Graduate students. Journal of educational psychology 2005;97(2);2005:268-274. https://doi.org/10.1037/0022-0663.97.2.268

[13]. Kourosh Amrai et al ; 2011 ; The relationship between academic motivation and academic achievement students ; procedia Social and Behavioral Sciences 2011;15:399-402. https://doi.org/10.1016/j.sbspro.2011.03.111

[14].Ungaro A. Pilates: Body in Motion ; Dorling Kindersley Publishing, Inc., London 2002.

[15]. Van der Geer et al. The art of writing a scientific article; Journal of Science Communication. 2000;163:51-59.

How to cite this article:

M. Sandhiya P. Senthil Selvam, M.S. Sundaram, Fouzia Banu. B. EFFECT OF YOGA AND PILATES ON ACADEMIC STRESS AMONG COLLEGE STUDENTS. Int J Physiother Res 2020;8(5):3563-3567. DOI: 10.16965/ijpr.2020.150 